\title{
鉄道のダイヤ
}

\section{Train Schedule}

\section{執筆者プロフィール}

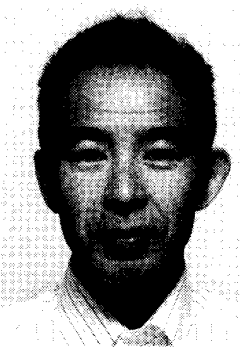

\section{坂口 隆}

Takashi SAKAGUCHI

口1997 年電気通信大学電気通信学部情報工学科 卒業, 1999 年電気通信大学大学院電気通信学 研究科（修士課程）修了

百として行っている業務・研究

・鉄道のスケジューリングアルゴリズムに関する

研究・組合せ最適化の理論とアルゴリズムに関 する研究

口所属学会および主な活動

日本オペレーションズリサーチ学会

懄務先

（財）鉄道総合技術研究所 主任研究員

（下185-8540 国分寺市光町 2-8-38

E-mail : saka@rtri.or.jp)

\section{1. はじめに}

定時運行を基本とした輸送サービス 業の中で日本の鉄道は世界一正確であ ると評されている，たとえば，インタ ネットの東海旅客鉄道 (株)（JR 東海） ホームページによると，2007年度 の東海道新幹線の平均遅延時分は，自 然災害によるものを含めても，1 列車 当たりわずか 20 秒である. 大量高密 度輸送を実現するためには, 綿密に計 算されたダイヤに従って列車を正確に 走らせる必要がある。しかし，輸送力 の限界に近い過密ダイヤで運行する大 都市圏では, 頻繁に遅れが発生してい るのもまた事実である，本稿では定時 性を確保する鉄道ダイヤのしくみと取 り組みにつて紹介する。

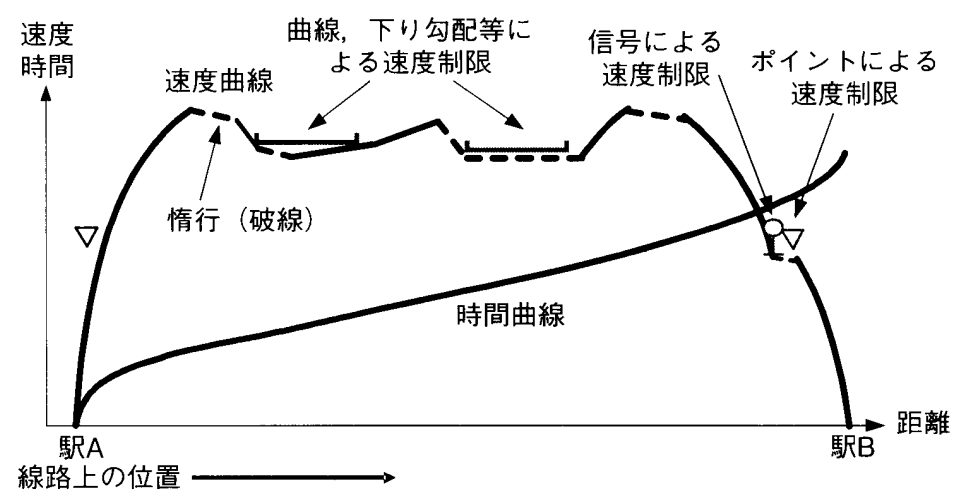

図1運転曲線図

\section{2. 鉄道ダイヤの作成}

\section{1 基準運転時分}

ダイヤの作成は，基準運転時分を求 めることから始まる。 これは，列車が ある駅を出発してから, 次の駅に着く までにかかる時間のことである. 列車 の条件（速度と引張力・ブレーキ力 . 走行抵抗の関係，乗客を含む列車重量 など), 線路の条件 (こう配, カ一ブ, トンネルなど), 運転状態（加減速 · 惰行）などから，ある地点をある速度 で走行しているときの加速度もしくは 減速度が求まる。線路の各地点には， 分岐器，下りこう配，カーブ、駅など による速度制限が与えられる。基準運 転時分は，これらの条件下で列車走行 のシミュレーションを行うことによっ て，標準的な走行パターン（これを運 転曲線という）を描き，そのときの運 転時間を基にして求められる（図 1). また, 駅と時間帯別に旅客が乗降に要 する時間を見積もって，これを基に基 準となる停車時分を求める。

\section{2 閉そくと時隔}

鉄道の安全を確保する基本となるの が「閉そく(閉塞)」である，閉そく は線路を一定の間隔に分割して，その 1 区間（閉そく区間）には1列車し
か入れないように信号機で制御するし くみである. 図2のように信号が先 行する列車の位置を示すとともに，赤 は停止, 黄は減速が義務づけられる。

列車が前方の列車の影響を受けずに 走るためには，常に青信号で通過でき るように間隔を取る必要がある。 そ のために，運転曲線から図 3 のよう なチャート図を作成し, 信号に引つか からずに走行できる最小の時間間隔 （これを続行時隔という）を算出する.

このほかにも，単線区間や折り返し 駅での対抗列車とのすれ違いや，列車 の追い越しなど，多くの局面に対して 列車間の競合を避けるための時隔を求 める必要がある.

\section{3 余裕時分}

さて，基準運転時分，停車時分，時 隔がそろうと，いよいよダイヤの作成 である. 時間帯ごとの目標とする輸送 量や保有する車両数を勘案しながら. 列車を 1 本ずつ設定していく（「スジ を引く」と表現する）が，基準運転時 分ぴったりに走るようにスジを引く と，何らかの原因で一度発生したわず かな遅れを回復できず, 先々の駅まで 遅れたままになる.また, 続行時隔ちょ うどの間隔でスジを引くと, 遅れが次 の列車にも影響して, 後々の列車まで 遅れることになる。 


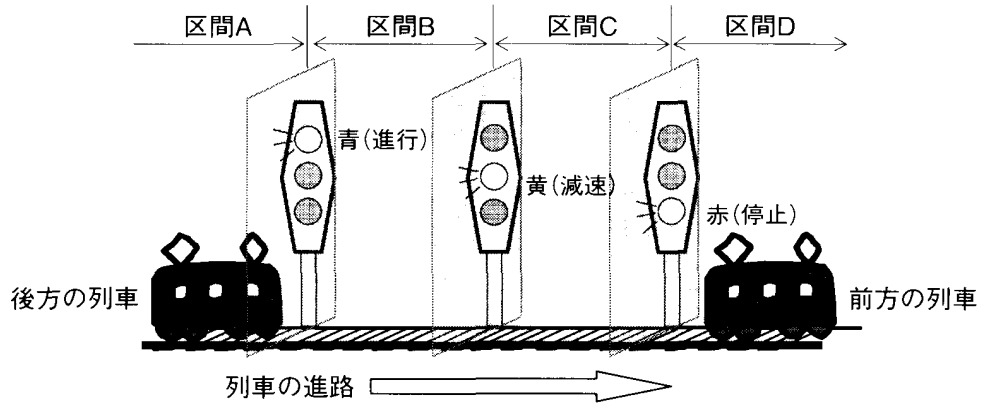

目 2 閉そくの概念

前方の列車が区間 Dに存在するときの各信号の状態を示す。閉そくは，後方の列車 が信岁の指示に従うことで，闹じ冈間に複数の列車が入らないようにして，列車の 安全を確保するしくみである
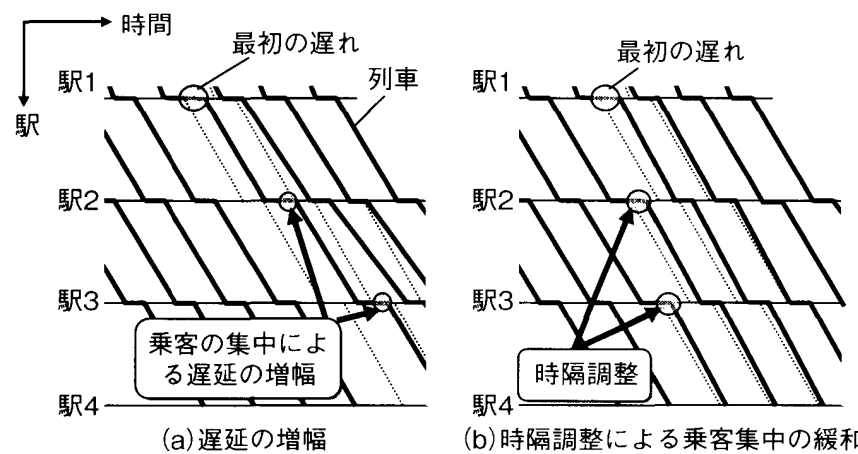

(b) 時隔調整による乗客集中の緩和

图 4 時隔調整

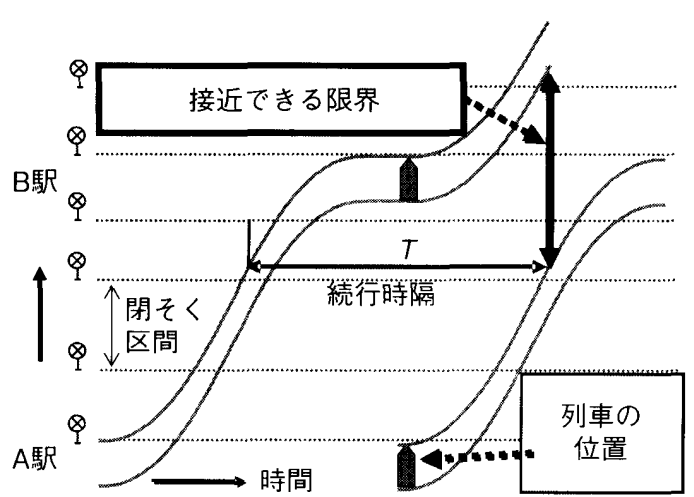

図 3 続行時隔の算出

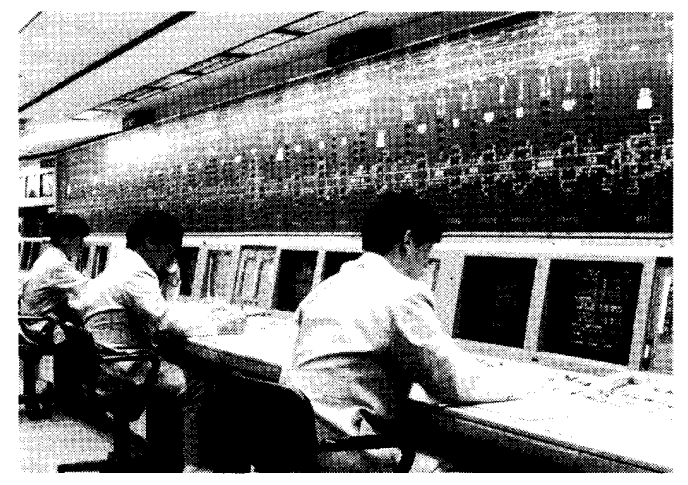

図 5 指令室の風景 (JR 西日本提供)
そこで，これらの事態を避け，少々 の外乱による遅れはすぐに回復できる ように，基準運転時分や停車時分に余 裕時分を加えた運転時分でスジを引 く，同様に運転間隔も時隔に適当な余 裕時分を付けた時間で設定していく

\section{3. ダイヤの遅れと対策}

\section{1 ダイヤの改善}

運転時分や運転間隔に十分な余裕を 持てば，遅れないダイヤになるだろう か，実はそう簡単な話ではない，都市 圏の輸送需要が高い路線では，むやみ に余裕時分を増やせば設定できる列車 の数が減り，その結果，ホームや車内 の混雑が増え，乗降時間亡走行時間が 延びて, 結局, 遅れがちなダイヤになつ てしまう可能性がある.したがって必 要な輸送力を確保しつつ, 必要最小限 の余裕時分を適切に配分しなければな らない.

ダイヤ改正では，運行管理の経験に 基づいて遅れがちな列車や駅を把握 し,ダイヤの改良, 調整を行っている. 近年, コンピュータによる列車進路制 御 (PRC: Programmed Route Control）が普及したことにより，電 子化された運行実績情報が蓄積される ようになった，そこでこれを使って運
行実績を分析し，輸送を改善する研究 が行われている(1)

\section{2 運行の制御}

都市圏のラッシュ時間帯では，比較 的小さな列車の遅れでも，それが次の 駅のホームの混雑を招き，利用客の乗 降時間が延びて遅れを拡大させ，後続 の列車にまで遅延が広がっていく〔図 4 (a)]. このような亜循環を避ける ため，図 4 (b) のように先行する何 本かの列車を意図的に少しずつ遅ら せ，見かけ上，最初の列車の遅延時分 を複数の列車と分け合う形にする. こ のような手配を時隔調整といい，1 列 車あたりの運転間隔の増加を収束可能 な程度まで小さくすることによって， 徐々に正常なダイヤに戻すことができ る.

このような運転の協調をコントロー ルするのは指令室の仕事である，指令 室では指令員が運行表示盤を常に監視 していて（図 5), 異常が発生すると 周りの運行情況を即座に判断して，駅 の信号を制御し，無線で乗務員と連絡 を取る，指令は鉄道運行の定時性を維 持する要であると言える.

\section{4. おわりに}

「ダイヤの遅れ」に関連した話題を
述べたが，ダイヤどおりに列車を運行 するためには，各列車に使用する車両 亡，担当する乗務員（運転士と車掌） を決める運用ダイヤを計画しなければ ならない，また，事故などで大幅に乱 れたダイヤを正常に戻すには，列車ダ イヤと運用ダイヤを緊急に組みなおす 作業（運転整理）が必要となる(2).

ダイヤのスケジューリングに関する 業務は, 長年の経験を積んだ専門家が， 多岐にわたる条件を総合的に判断して 行っており,より便利なダイヤを提供 するために，条件や目的が今後ますま す複雑化·多様化する傾向にある。 た，職人と呼ばれる人たちのいわゆる 大量退職の時代を迎えている。鉄道の 将来のためには, 輸送業務のIT 化と 最適化技術の高度化による，スケ ジューリングの自動化 ${ }^{(3)}$ が緊急の課題 である.

\section{文 献}

（1）武内陽子.富井規雄・泉利克, 列車運行实績分析システム ( Plan の作成とその試用例。第 43 屾鉄道 サイバネシンポジウム論文集. (2006-12), 131-136.

（2）富井規雄，列車ダイヤのひみつ, (2005)，成川掌.

（3）鉄道総合技術研究沂 連転システ ム研究公. 鉄道のスケジューリン グアルゴリズム。(2005)。NTS 